\title{
『公私協働とネットワーク化による教育運営サポートシステム の構築に関する国際比較研究』(研究代表者: 宮腰英一)
}

本書は学会研究委員会が企画し、平成 16 ～18年度の 3 ケ年にわたり研究分担者 18名之研究協力者 11 名によって遂行され た調査研究の成果である。調査対象国・ 地域及び執筆者は次の通り。課題設定 (宮 腰)、英国 (望田研吾、吉原美那子、白幡 真紀)、米国(二宮皓、佐々木司、中島千恵)、 ロシア (澤野由紀子)、フィンランド (渡邊 あや)、中国 (大塚豊)、韓国 (石川裕之)、 タイ (森下稔、村田翼夫)、ベトナム (浜 野隆)、インドネシア (服部美奈)、オース トラリア (伊井義人)、オセアニア地域 (伊 井、高橋望)、チリ(斉藤泰雄)、アフリカ(浜 野隆)、国内調査 (井本佳宏、金井徹、高 橋望、白旗悠、平中里弥、本底麻依子)。

今日、私的セクターとの連携協力関係な くして公教育政策の遂行はありえない。否、 私的セクターの増殖は国家自体の意思決 定を左右する所まで来ている。国や地方自 治体は公教育政策の実施にあたって、学 校施設管理・運営の業務委託、PFI、官民 連携による学校設置や経営、教育経営の 包括的外部委託など、多様な形態の公私 協働関係を築いている。本研究はこうした 状況を踏まえ、競争的環境にある学校が 安定的で効果的に運営されるために公私 協働と制度的ネットワーク化によるサポー トシステムがどのように構築されているの か、その構造、機能、運営について国際 比較により解明することを目的とした。
教育における公私協働の議論は、公共 サービスの供給主体の民間への開放や市 場競争による効率的で質の高いサービス の提供を目指した「新公共経営」(NPM) と呼ばれるアングロサクソン系諸国の行 財政改革に始まる。この動きはWTO、 OECD、世界銀行など国際機関や多国籍 企業を媒体に、経済のグローバル化の潮 流に乗りながら地球規模で拡大した。そ の内容と程度に差異はあるものの、ロシ ア連邦での学校教育の民営化や脱国家化 の進展、中国における「公私混合型学校」 の出現、米国のチャータースクールをモ デルとした韓国の「開放型自律学校」の 試み、タイにおける法人格を付与された 「学校を基盤とする経営」をサポートする 教育地区の設置、教育バウチャーの導入 や教員の非公務員化を断行したチリ、ア フリカ諸国における世界銀行の民営化推 進策と公私協働による学校設置の拡大な ぞ、社会主義諸国や途上国においても公 私協働の少なからぬ影響が認められる。

それゆえ教育分野においても垂直的官 僚組織に代わって、公的セクターのみなら ず企業、民間団体、NPO、市民など多様 なアクターが相互に連携しながら課題解決 を図るネットワーク型ガバナンスの構築が 求められる。公私協働は公私を媒介する民 が支える公共領域の形成に連なるものであ る。(A 4判、320頁、非売品、2007年) 